\title{
The uneven and combined development of labour forms
}

This article is forthcoming (2014) in Capital E Class, 38(1): 129 - 141.

Nick Taylor

\begin{abstract}
This article seeks to elaborate a framework for the study of diversity in forms of labour using Trotsky's theory of uneven and combined development (U\&CD). It argues that labour markets are constituted by systemic processes of capital accumulation and uneven development in the global economy, but that these processes have highly differentiated outcomes in terms of the forms of labour that have historically emerged within and across national boundaries. Exploring some of the neglected elements of different forms of labour, including non-waged labour, the article demonstrates how we might conceptualise the way in which combinations of labour forms exist within any given space of the world economy. Using the examples of both internal and transnational migration it argues that charting the social and spatial relations of production, and the labouring experiences and forms of worker politics associated with them, is an effective way of understanding the constitution and restructuring of different forms of labour.
\end{abstract}

Keywords: Varieties of capitalism; Trotsky; uneven and combined development; labour 


\section{Author biography}

Nick Taylor is a PhD candidate in the Department of Politics and International Studies at the University of Warwick, UK. His research examines the relationship between the history of economic thought and the history of relief and welfare in Britain from the late $19^{\text {th }}$ century onwards, specifically exploring the development of theories of value.

Corresponding author: Nick Taylor, n.j.taylor@warwick.ac.uk 


\section{Introduction}

The literatures on capitalist diversity need to contend with a difficult question: how should we theorise the general or systemic properties of the global economy against the empirically complex particularities of capitalist development at any given spatial scale? Such a question forces us to consider the validity of general laws of economic development, to confront the challenge of analysing multiple spatial scales of the global economy simultaneously and to pay due attention to substantive differences in the experience of economic development. This article makes an effort to tackle these challenges through an exploration of the diversity of forms of labour that exist throughout the world. It argues, using Leon Trotsky's theory of uneven and combined development (U\&CD), that labour markets are constituted by systemic processes of capital accumulation and uneven integration into the global economy. The unevenness of capitalist development leads to differential outcomes in the combination of different forms of labour that exist within any given space. A better understanding of these forms, and the way in which they are constituted and come together through transnational or inter-societal processes, gives us an empirically clearer picture of capitalist diversity and a means of theorising its dynamics from labour's perspective.

Just over a decade ago, International Political Economy (IPE) could be justly accused of ignoring 'the agency of non-elite groupings of people' and, more precisely, of neglecting both empirically and theoretically the role of workers in the world economy (O'Brien, 2000: 89). Today, there is a more extensive literature on transnational labour processes to draw upon (e.g. Silver, 2003; Munck, 2004; Bieler and Lindberg, 2010). In this article, I outline the beginnings of a general framework for studying different 'forms' of labour that will be complementary to this literature but in contention with the varieties of capitalism (VoC) approach. It should therefore be considered partially as a critique of current heuristic frameworks and partially as a tentative elaboration of an alternative. I situate this alternative within what has been called the 'neo-Trotskyist' approach to historical sociology (Hobson, 2011), but also take inspiration from other disciplinary areas, including social history and political geography. In addition, the article engages with some of the more recent institutional approaches to capitalist diversity. The spirit of the article might be captured best in van der Linden's (2003: 3) claim that 'we can only discover what is specific and what is 
general in our own history by looking beyond national borders'. What is sought is a disaggregated view of labour markets, where features of workers' experiences and agency are identified, but also understood as both productive of, and constituted by, inter-societal, or transnational contexts.

\section{The heuristics of comparative analysis}

The early VoC literature explored the idea of different national models of capitalism based on the comparative advantage offered by different institutional arrangements (Hall and Soskice, 2001). Hall and Soskice's stated aims were to 'construe the key relationships in the political economy in game-theoretic terms and focus on the kinds of institutions that alter the outcomes of strategic interaction' (ibid.: 5 ). Notwithstanding that this required bending to the controversial behavioural assumptions of game-theoretic models, it also focused attention on firms and not the workers within firms. While it did not entirely avoid the issue, the process by which the VoC approach investigated labour involved a privileging of certain types, namely industrial labour, and then often only to remark on strength of unionisation against employers' capacity to set wages (e.g. Soskice, 1999: 106-110). The defining institutional nexus was, according to Thelen, the 'connection between national collective bargaining structures and plant-level strategies' (Thelen, 2001: 72; also Golden et al., 1999). Subsequently, a country's labour market was categorised by the traits of its collective bargaining structures and given membership to a group of countries that define one of the two basic models of capitalism - either a coordinated market economy (CME) or a liberal market economy (LME). This division of national capitalisms is the basic heuristic device that VoC authors employ to sensitise us to the notion of divergent, or at the very least different, national capitalisms.

The key problem is that, by accepting this means of categorising national capitalisms, we are accepting that there is a singular institutional logic that determines the variety in question and thus reifying those institutional arrangements, and that national 'model'. On the face of it, the main criticism is obvious: as Hanson and Teague conclude, '[r]eally existing capitalism comes in more than two varieties' (2007: 163). The problem, however, goes deeper than this; VoC authors willingly acknowledge the existence of 'more than two varieties'. Hall 
and Soskice contend that 'the point of the analysis [is] not simply to describe two types of economies but to develop new formulations about the principal dimensions distinguishing one political economy from another in more general terms' (2003: 243-4). Through generating these formulations, however, not only was the VoC framework narrowly 'firmcentred' (Deeg and Jackson, 2007) but also '[c]onceptual claims about the existence of distinct national capitalisms [were] often treated as if they were empirical analyses of actual economic experiences' (Watson, 2003: 230). It is these economic experiences, from the point of view of the worker, which this article attempts to present as a defining element of diversity in the world economy.

Efforts have been made to expand understandings of institutions and the actors which constitute them. Boyer (2005: 520), for example, argues that there are 'at least four forms of capitalism' and employs regulation theory to increase the number of mediating factors that define capitalist diversity, such as the 'wage-labour nexus' and 'monetary regimes'. Other analyses have argued that we should move away from the nation as a unit of analysis and instead envision capitalist diversity at different conceptual levels (Deeg and Jackson, 2007). Still others have sought to preserve the nation-state as the basis for ideological and material constructions of institutional practices while arguing that there has been a 'growing transnationalization of the institutions and practices of capitalism' (Radice 2000: 737). There is also the possibility that we might do better to unseat the notion of institutions as separate from greater socioeconomic logics. On this point Bruff (2011: 482) asserts that institutions are socially embedded within capitalist constraints, both material and ideational, and we should therefore be looking at the issue of difference as one of 'varieties in capitalism.' Nevertheless, this still leaves open the question: varieties of what?

Undertheorised in both $\mathrm{VoC}$ and institutionalist approaches to capitalist diversity is something central to the U\&CD approach: the world economy. The VoC approach conceives of the world economy as an aggregate of distinct national models; U\&CD, by contrast, conceives of it as a single entity where the systemic logic of capital accumulation draws together its component parts into an overarching structure. States play an important constitutive role in this latter conception of the world economy. But so too do finance, intercapitalist rivalry, the productivity of labour and a hierarchy of nations, or what Trotsky called an 'imperialist chain' (Ashman, 2006: 96). The main argument in this article is that diversity within the social relations of production is another important factor that shapes the politico- 
economic landscape of the world economy. Analysing this diversity can provide some important correctives to the narrowness of $\mathrm{VoC}$ and institutionalist approaches to labour. It might also point to ways in which different forms of labour are themselves hierarchically ordered, with some even functioning merely as a means to sustain others. Furthermore, we might acknowledge how uneven development and the particularity of the labouring experience itself affects the character of labour struggles.

This means that simply expanding the potential number of models of capitalism will not do; further conceptual unpacking of production relations is necessary. For example, both the VoC literature and other institutionalist approaches focus on wage-labour - often, as has been mentioned, on its industrial, unionised form, with complete disregard for non-waged forms of labour. Yet, as van der Linden has argued, 'there is an almost endless variety of producers in capitalism, and the intermediate forms between the different categories are fluid rather than sharply defined' (2008: 22). The task thus becomes one of generating a theoretical framework to deal with such heterogeneity. Inevitably, it involves a process of categorisation. I argue that an effective way of conceptualising different categories is through an analysis of different forms of labour, with the two key elements of any form being: (1) the labouring experience of the work itself; and (2) the relationship between the producer (or worker) and those individuals or group of individuals who exercise control over them in the labour process. Before giving examples of these forms, and to understand how we might conceive them to be constituted in an uneven and combined context, it is necessary to turn to Trotsky's theory.

\section{A Trotskyist approach to the diversity of labour forms}

U\&CD was part of Leon Trotsky's theoretical apparatus for understanding the historical development of Russian society. The seeds of the theory can be traced to his writings on 'permanent revolution' from 1905 onwards, in which he elaborated a Marxist analysis of the Russian revolution of that year and of world capitalist development in general, arguing that the former had been conditioned by Russia's relations with the latter (Radice and Dunn, 2006: 4-5). These ideas came to fruition in his History of the Russian Revolution, in which he stated that ' $[\mathrm{u}]$ nder the whip of external necessity, [a] backward culture is compelled to make leaps' across historical stages (Trotsky, 2008: 5). In this way, the unevenness of the world 
capitalist market exerts pressure on more 'backward' countries, which in turn 'combine' different stages of historical development - 'an amalgam of archaic with more contemporary forms' - in order to arrive at a more advanced point (ibid.: 5). Trotsky himself never extensively elaborated his theory of U\&CD; those seeking to employ U\&CD today can draw on selections of his work, as well as a variety of Marxist scholars including Ernest Mandel and George Novack (van der Linden, 2007).

In the past few years, there has been a revival of interest in Trotsky and U\&CD as a means to understanding trends in social development. Rosenberg (1996; 2006; 2010) has led the charge, sticking closely to Trotsky's original stance that unevenness is 'the most general law of the historic process' (Trotsky 2008: 5). Focusing on the relationship between geopolitics and class conflict, he has sought to derive the fact of political multiplicity - the existence of many societies - from an explanation of social development as uneven and combined (Rosenberg, 2010). Other contributions have dealt with a number of different topics, including: late development (Selwyn, 2011); transnational labour solidarity (Bieler, 2012); and Atlantic slavery (Shilliam, 2009). Some accounts - such as Morton's work on state formation in Mexico concentrate on how class strategies that are foundational to state formation and the establishment and deepening of capitalist relations have operated in the context of uneven development, in his case by using Gramsci's concept of 'passive revolution' (Morton, 2011; see also Allinson and Anievas, 2010). This article contains less of a historical sweep than most of the above literature and concentrates on one aspect of multiplicity: forms of labour. A major point of contention is that, in contrast to the VoC approach, each country may not be defined by one form of labour, labour politics or labour market institution. Indeed, quite the opposite is true. There is an abundance of labour forms that exist within nation-states, and in every country there exists a combination of different types of labour. If this is the case, then the variations of capitalist labour and the space they occupy are, in essence, a matter of varieties of combinations of these different labour forms and not simply varieties of labour forms themselves.

This leaves us with a picture of labour markets that is far more disaggregated than any VoC or comparative institutionalist approach has yet shown. Concentrating on workers' experience of the labouring process as suggested above, however, has the potential to generate a number of labour forms beyond conceptual usefulness. As Amoore (2006: 18) has noted, '[w]orkers express a multitude of contradictory and contingent subjectivities when 
deciphering their experiences of restructuring, and are differentially inserted into relationships with one another and with global sections of capital'. The need to choose typologies means we are necessarily limiting the scope and nuance of the analysis. Nevertheless, there are several sources from which to obtain a ready-made typology or categorisation of labour forms. Harrod, for example, identifies six prominent types of 'unprotected worker', all of whom are 'subordinate workers within subordinate forms of social relations' (Harrod, 1987: 2) and a total of twelve forms of social relations of production (ibid.: 15-18). Unprotected workers may include wage-labourers in the textile industry susceptible to labour law infringements. They may, on the other hand, be housewives subjected to patriarchal tradition, consigned to childbearing, childrearing and other household services tasks that, without remuneration, nevertheless 'become a supportive base for all other forms of social relations' (ibid.: 308). For lack of space, it is not possible to settle on and discuss a full typology of labour forms here; yet there is room to review some of the important elements of what should be incorporated, including what has so far been overlooked.

As already stated, non-waged forms of labour constitute a significant yet neglected realm of capitalist diversity. There has been a growing literature on 'precarious' forms of labour: workers often distinguished as those most affected by the decline in labour-market securities associated with the post-war welfare state and the rise of market-led, flexible working practices (Standing, 2011). Without belittling the insecurities resulting from the withdrawal of social protections, such an idea of the 'typical' worker might be radically displaced by casting our analysis of labour forms over a wider range or even overturning our conceptions of labour altogether. In a thought-provoking intervention, Denning argues that 'capitalism begins not with the offer to work, but with the imperative to earn a living' (Denning, 2010: 80). He urges us to 'imagine the dispossessed proletarian household as a wageless base of subsistence labour - the 'women's work' of cooking, cleaning and caring - which supports a superstructure of migrant wage seekers who are ambassadors, or perhaps hostages, to the wage economy'. The result is that ' $[\mathrm{u}]$ nemployment precedes employment, and the informal economy precedes the formal, both historically and conceptually' (ibid.: 81); the absence of a job, or 'wageless life', becomes the basis from which to understand the labour market, rather than only an unwelcome consequence of it.

There are also more detailed explorations of the labouring experience and relations of production to draw upon. Hochschild's study of 'emotional labour', which signifies the 
'management of feeling to create a publicly facial and bodily display', is one such example (Hochschild, 2003: 7). Such labour is undertaken to sell a service or product and affect a desire to purchase or a positive feeling in the consumer or subject. Simultaneously, a worker can seek to affect this desire (affective labour), while performing certain emotions and concealing others (emotional labour), in order to sell a good or service. Emotional labour thus takes the shape of an exchangeable commodity and is associated with feelings of alienation in the workplace that derive from 'the task of managing an estrangement between self and feeling and between self and display' (ibid.: 131). It often entails the transposition of aspects of unwaged work in private settings - caring roles in particular - to waged work in the services industry. Generally, it has been associated with the rise of 'immaterial' labour in the service sector, considered immaterial 'in the sense that its products are intangible, a feeling of ease, well-being, satisfaction, excitement, or passion' (Hardt and Negri, 2000: 293). This research points to the way in which the relationship with the product of labour shapes the experience of the labour process in various ways.

These two forms of labour alone - subsistence or socially reproductive labour and emotional labour - serve as evidence of the narrowness of $\mathrm{VoC}$ and other institutionalist literatures when it comes to labour. It seems wrong to argue for either the case of convergence or of variety on the basis of national models, when the diversity of labour experiences and relations is so abundant. Every economy has a combination of different labour forms and, what becomes apparent when undertaking a typology of such forms, is that they are not always distinct - an unprotected worker, for example, may also be engaging in emotional labour. As Watson (2003: 238) has argued, 'a single national "model” of capitalism sustains a whole range of different experiences of the economy, depending upon the way in which different people are socialized into the economy, as well as being socialized into expecting to perform particular types of economic roles'. It is important, therefore, to delimit the study in some way but not at the expense of paying attention to the existing differences of labour experience and not through submitting to national labour market models as per the VoC framework. The article will now construct an alternative heuristic design based on the conceptualisation of combinations of labour forms (and therefore the social relations of production they exist within), arguing that it is possible to have a framework where structural, systemic change is connected to the experiences, political subjectivities and relations of power associated with particular types of labour. 


\section{The inter-societal constitution of labour forms}

In order to argue that combinations of labour forms are established in an interactive and inter-societal context, it is necessary to account for the idea of U\&CD across different geographical scales. For Trotsky, the notions of unevenness and combination followed from his conception of the world market, which, as it undergoes 'a unified process of capitalist development...absorbs all the countries it meets on its way and creates in them a social amalgam combining the local and general conditions of capitalism' (Trotsky in Knei-Paz, 1978: 88). Conceived this way, we might acknowledge that the globe is bound together by an ever-proliferating international division of labour which links together producers, if only in an impersonal manner, through commodity exchange and production. But this tells us little about how combinations of labour forms are established, how they contribute to institutional structures associated with production, or how they have changed over time. For that, a concrete process of inter-societal, and intra-societal, relations must be identified and probed further. As inspiration, Bieler (2012) and Herod (2006) have both used U\&CD to point to the way in which labour can operate in a transnational setting to actively constitute the geography of capitalism through either promoting or rejecting transnational solidarity between different labour organisations, as well as through engaging in strategies of 'boosterism' to attract investment to their communities. With regard to the uneven and combined development of labour forms, and specifically the idea of a multiplicity of labour forms, I suggest that migration might be another such concrete process.

In exploring the uneven nature of the world economy and its effect on labour forms it is important that workers are not merely considered pawns. As Amoore (2006: 14) argues, too often analyses of the nature of structural change in the global political economy have rendered invisible the everyday lives, experiences and agency of workers, 'positioned [them] passively outside the process, receiving the imperatives of global restructuring.' We should note how contestation of structural change itself enacts institutional change and shapes a specific and geographically defined politics of resistance. In this respect, an illuminating case is the internal, regional migration of workers within China. Ching Kwan Lee's (2007) landmark study of Chinese labour politics explores the differences between worker protest in 
the de-industrialised 'rustbelt' province of Liaoning in the northeast and those in the 'sunbelt' export manufacturing province of Guangdong in the south; it is exactly the kind of sociology that complements U\&CD as an approach to capitalist diversity. Lee charts the differences of approach to protest that 'veteran' workers take in the rustbelt - predominantly street demonstrations and appeals to the fading 'socialist social contract' (ibid.: 71) - against those that are taken by young Chinese migrants in the sunbelt, who instead take recourse to the law courts and labour bureaucracy to make their demands (ibid: 159).

From our U\&CD perspective we can supplement such an analysis through the acknowledgement that the 'whip of external necessity' has had a constitutive effect on China's political economy. The dramatic reorientation of the country towards large-scale manufacturing for Western consumer markets, and the wider neoliberal modernisation programme following the ascension of Deng Xiaoping in 1978, were evidently spurred by a consciousness of backwardness and an explicit desire to catch-up, not only with the West but also with China's competitors in East and South-east Asia (Harvey, 2005: 120). The establishment and consolidation of capitalist social relations in China might be considered as typical of a state-led project of 'permanent primitive accumulation' and passive revolution (Morton, 2011: 37). That there has been such a large and rapid decline in the number of workers living in poverty in the East Asian region (below US\$1.25 per day) - a reduction of 158 million since 2000, 24 million since 2007 (ILO, 2012: 41) - demonstrates the macro-impact of such developmental catch-up strategies but not its micro-effects on the experiences of Chinese workers and the changed nature of worker politics. For that, we need to adopt a disaggregated view of the labour market such as Lee's, which explores the effect that displacement has had on young migrants and that stasis has had on workers in the former industrial heartlands.

Transnational migration has also begun to play a greater constitutive role in the shaping of the world economy. This has led to increasing attention from international organisations and governments around the world on the relationship between migration and development. Phillips' research on Latin America and the Caribbean points to the articulation of a new developmental strategy of migration in the face of world economic pressures and 'the pronounced contraction of existing and potential development spaces' in the region (Phillips, 2009: 232). Countries such as Mexico are following a still-incoherent but increasingly recognisable development tactic of easing the passage of emigration to developed countries, 
particularly the United States, while attempting to control the flow of remittances back into their economies. Such a transnational division of labour is constitutive of the role of migrant labourers in an 'emerging political economy of inequality' (ibid.: 246), which affects receiving countries' labour markets - by depressing wages and loosening employment rights - as well as those of sending countries.

Some have attributed this to uneven development more broadly, and pointed directly to neoliberal capitalist restructuring in the Global South, which is forcing a so-called surplus labour population to emigrate to developed countries only to experience extreme exploitation and criminalisation on arrival (Delgado Wise and Márquez Covarrubias, 2011). This position of the migrant in a transnational division of labour is increasingly being driven by neoliberal attempts at 'migration management' (Kalm, 2010). The latest trend in this regard is the promotion of 'circular migration' through 'regularized temporary programmes' that feed the demand for flexible labour forces in developed countries (ibid.: 37). Through these and other arguments, we are forced to confront migration simultaneously as a consequence of world economic pressures and as productive of novel and increasingly prominent forms of labour market stratification as well as attempts at new strategies of neoliberal global governance; it is, in a sense, both the source and the effect of the world economy's 'external whip'.

We would do well at this point not to abandon the initial challenge of theorising worker experiences, not merely alongside but in interaction with the more systemic trends of uneven development. There are a multitude of avenues to explore in this regard. For example, feminist scholars have built on the concept of global commodity chains to develop the idea of 'global care chains' (Hochschild, 200o). This is an idea that attempts to conceptualise the internationalisation of care work (which itself includes various types of care, from childcare to sexual services) and ascertain the importance of statist forms of regulation vis-à-vis the numerous formal and informal transnational networks that structure the channels of migrant labour care globally (Yeates, 2004). Of particular importance too are the common experiences of the undocumented migrant, a figure that has been branded by its 'disposability', not least in the labour process (De Genova, 2010: 46). Such migrants are defined by citizenship only in so far as they remain outside of it; 'this peculiar sociopolitical relation of juridical nonrelationality', writes De Genova, is the material and practical precondition for [their] thoroughgoing incorporation within a wider capitalist social formation, in which an effectively global market is fractured systemically into a political order of territorially 
delimited nation-states' (ibid.: 47). Again, transnational migrants are not only impelled to move because of the unevenness of the world economy; they constitute part of that very unevenness through their movement, too.

Drawing on the understanding of a labour form outlined previously, we can point to how the undocumented migrant's experience of work is characterised by this issue of legality. Their labouring experience itself is likely to be defined by their separation from, in developed countries, a community of (relatively) secure workers and by a lack of rights and safety as well as extreme precariousness more generally. In terms of the relationship with those who exercise control over them, the prospect of detention and deportation confronts them both in and outside of work and is enforced by a number of groups and actors - their employer, a trafficker, the border agency and police force, private security firms - many of whom are representative of, or operate on behalf of, the sovereign state, standing in opposition to the migrant's undocumented status. The relationship with their employer is therefore intensified, seeing as they are dependent on his or her goodwill for the continuation of their stay in any given country and that they may be susceptible to the more pernicious forms of non-wage labour, such as slavery (Burnett and Whyte, 2010). As migrants, they are also subject to racism and xenophobia, which, as anti-immigrant violence in Greece attests to, have been amplified since the advent of the economic crisis, mass unemployment and social breakdown. However, the figure of the undocumented migrant also represents defiance of a bordered world and sovereign power, and must not be rendered passive in this regard. In sum, we might not characterise migrant labour as a singular form of labour, but instead attribute a common cluster of labour forms and attendant experiences to the category.

\section{Conclusion}

U\&CD provides an alternative form of systemic analysis that does not render invisible the multitudinous forms of labour, and actively encourages us to see them as combinations that exist at various different scales of the world economy. It also has a dedication to revealing the continuous struggles of workers attempting to shape their own lives, sometimes, such as in the case of the 'unprotected' or undocumented worker, under oppressive and harsh circumstances. In this respect, it puts emphasis on the potential for transforming the 
relations of production where other approaches take them to be largely immutable, dependent on elite-level institutional change. Capitalism forms through uneven, 'geographically differentiated' development which tends to concentrate powerful productive centres of capital and labour in metropolises, (Harvey, 2006: 416) through which we might identify combinations of labour forms. What we can take from a U\&CD perspective is that the dynamics of capitalism, while powerful and in certain respects homogenising, necessarily interact with local conditions and people who are seeking to preserve or determine their own positions in society. With regard to the case of diverse labour forms, this offers a powerful alternative to the $\mathrm{VoC}$ and broader institutionalist approaches.

The arguments for making the workers of the world visible subjects in both theories of the workplace and the world economy are strong. This article has tried to construct several levels of critique and proposal. Perhaps the overriding point, though, has been to develop a theoretical and heuristic framework that injects social and spatial history into our understanding of labour and the world economy. As an exercise it also urges us to overcome the disciplinary gaps in the VoC and broader institutionalist approaches. Without attempting to understand the differentiation of labour experiences, the coterminous nature of sociological and international development and the systemic tendencies of the capitalist world economy, this is a futile exercise. U\&CD teaches us that the social relations of production are in permanent revolution; it is our task to discover their results and shape their prospects.

\section{Acknowledgement}

A previous, German-language version of this article - entitled " - was published in Peripherie...

I would like to thank Ian Bruff, Matthias Ebenau, Justin Rosenberg, Matthew Watson, Andreas Bieler and the anonymous reviewers for their comments and advice on earlier drafts of this article. Any mistakes or incoherencies are, of course, my own responsibility. 


\section{References}

Amoore L (2006) Invisible subject(s): Work and workers in the global political economy. In Davies M, Ryner M (eds.) Poverty and the Production of World Politics: Unprotected Workers in the Global Political Economy. Basingstoke: Palgrave Macmillan.

Ashman S (2006) From world market to world economy. In Dunn B, Radice H (eds.) 100 Years of Permanent Revolution: Results and Prospects. London: Pluto.

Bieler A, Lindberg I (eds.) (2010) Global Restructuring, Labour and the Challenges for Transnational Solidarity. Abingdon: Routledge.

Bieler, A (2012) The EU, Global Europe, and processes of uneven and combined development: The problem of transnational labour solidarity. Review of International Studies 39(1): 16183.

Boyer R (2005) How and why capitalisms differ. Economy and Society 34(4): 509-57.

Bruff I (2011) What about the elephant in the room? Varieties of capitalism, varieties in capitalism. New Political Economy 16(4): 481-500.

Burnett J, Whyte D (2010) The Wages of Fear: Risk, Safety and Undocumented Work. Positive Action for Refugees and Asylum Seekers report, at www.pafras.org.uk/wpcontent/uploads/2011/o1/The Wages of-Fear.pdf, accessed 21/02/2013.

Deeg R, Jackson G (2007) Towards a more dynamic theory of capitalist diversity. Socioeconomic Review 5(1): 149-79.

de Genova, N (2010) The deportation regime: Sovereignty, space and the freedom of movement. In de Genova N, Peutz N (eds.) The Deportation Regime: Sovereignty, Space, and the Freedom of Movement. Durham, NC.: Duke University Press.

Delgado Wise R, Márquez Covarrubias H (2011) The dialectic between uneven development and forced migration. In Faist T, Fauser M, Kivisto P (eds.) The Migration-Development Nexus. Basingstoke: Palgrave Macmillan.

Denning M (2010) Wageless life. New Left Review 2(66): 79-97.

Golden M, Wallerstein M, Lange P (1999) Postwar trade-union organization and industrial relations in twelve countries. In Kitschelt H, Lange P, Marks G, Stephens J (eds.) Continuity and Change in Contemporary Capitalism. Cambridge: Cambridge University Press. 
Hall PA, Soskice D (2001) An introduction to varieties of capitalism. In Hall PA, Soskice D (eds) Varieties of Capitalism: The Institutional Foundations of Comparative Advantage. Oxford: Oxford University Press.

Hall PA, Soskice D (2003) Varieties of capitalism and institutional change: A response to three critics. Comparative European Politics 1(2): 241-50.

Hanson P, Teague E (2007) Russian political capitalism and its environment. In Lane D, Myant M (eds.) Varieties of Capitalism in Post-Communist Countries. Basingstoke: Palgrave Macmillan.

Hardt M, Negri A (2000) Empire. Cambridge, MA.: Harvard University Press.

Harrod J (1987) Power, Production and the Unprotected Worker. New York: Columbia University Press.

Harvey D (2005) A Brief History of Neoliberalism. Oxford: Oxford University Press.

Harvey D (2006) Limits to Capital (2 $2^{\text {nd }}$ ed.). London: Verso.

Herod A (2006) Trotsky's omission: Labour's role in combined and uneven development. In Dunn B, Radice H (eds.) 100 Years of Permanent Revolution: Results and Prospects. London: Pluto.

Hobson JM (2011) What's at stake in the neo-Trotskyist debate? Towards a non-Eurocentric historical sociology of uneven and combined development. Millennium 4o(1): 147-66.

Hochschild AR (200o) Global care chains and emotional surplus value. In Hutton W, Giddens A (eds.) On the Edge: Living with Global Capitalism. London: Sage.

Hochschild AR (2003) The Managed Heart: The Commercialization of Human Feeling (2oth Anniversary Edition). Berkeley, CA.: University of California Press.

International Labour Organisation (2012) Global Employment Trends 2012. Geneva: International Labour Office.

Kalm S (2010) The political rationality of migration management. In Geiger M, Pécoud A (eds.) The Politics of International Migration Management. Basingstoke: Palgrave Macmillan.

Knei-Paz B (1978) The Social and Political Thought of Leon Trotsky. Oxford: Clarendon Press.

Lee CK (2007) Against the Law: Labor Protests in China's Rustbelt and Sunbelt. Berkeley, CA.: University of California Press.

Morton AD (2011) Revolution and State in Modern Mexico: The Political Economy of Uneven Development. Lanham, MD.: Rowman \& Littlefield. 
Munck R (2004) Labour and Globalisation: Results and Prospects. Liverpool: Liverpool University Press.

O’Brien R (200o) Labour and IPE: Rediscovering human agency. In Palan R (ed.) Global Political Economy: Contemporary Theories. London: Routledge.

Phillips N (2009) Migration as development strategy? The new political economy of dispossession and inequality in the Americas. Review of International Political Economy 16(2): 231-59.

Radice H, Dunn B (2006) Permanent revolution: Results and prospects 100 years on. In Radice H, Dunn B (eds.) 100 Years of Permanent Revolution: Results and Prospects. London: Pluto.

Rosenberg J (1996) Isaac Deutscher and the lost history of international relations. New Left Review 1(215): 3-15.

Rosenberg J (2006) Why is there no international historical sociology? European Journal of International Relations 12(3): 307-40.

Rosenberg J (2010) Basic problems in the theory of uneven and combined development. Part II: Unevenness and political multiplicity. Cambridge Review of International Affairs 23(1): 165-89.

Selwyn B (2011) Trotsky, Gerschenkron and the political economy of late capitalist development. Economy and Society 40(3): 421-50.

Shilliam R (2009) The Atlantic as a vector of uneven and combined development. Cambridge Review of International Affairs 22(1): 69-88.

Silver BJ (2003) Forces of Labor: Workers' Movements and Globalization since 1870. Cambridge: Cambridge University Press.

Soskice D (1999) Divergent production regimes: Coordinated and uncoordinated market economies in the 1980 os and 1990s. In Kitschelt H, Lange P, Marks G, Stephens J (eds.) Continuity and Change in Contemporary Capitalism. Cambridge: Cambridge University Press.

Standing G (2011) The Precariat: The New Dangerous Class. London: Bloomsbury.

Thelen K (2001) Varieties of labor politics in the developed democracies. In Hall PA, Soskice D (eds.) Varieties of Capitalism: The Institutional Foundations of Comparative Advantage. Oxford: Oxford University Press.

Trotsky L (2008) History of the Russian Revolution, trans. M. Eastman. Chicago: Haymarket 
Books.

van der Linden M (2003) Transnational Labour History: Explorations. Aldershot: Ashgate. van der Linden M (2007) The 'law' of uneven and combined development: Some underdeveloped thoughts. Historical Materialism 15(1): 145-65.

van der Linden M (2008) Workers of the World: Essays Toward a Global Labor History. Leiden: Brill.

Watson M (2003) Ricardian political economy and the 'Varieties of Capitalism' approach: Specialization, trade and comparative institutional advantage. Comparative European Politics 1(2): 227-40.

Yeates N (2004) Global care chains. International Feminist Journal of Politics 6(3): 369-91. 